УДК 303.442.23:[930.85:39(497.7)'’20",

https://doi.org/10.55302/MF2180007p

Весна Петреска

\title{
АРХИВСКИТЕ И ТЕРЕНСКИТЕ ИСТРАЖУВАҢА КАКО ПРЕДИЗВИЦИ НА ФОЛКЛОРИСТИЧКИТЕ ИСТРАЖУВАҢА ВО ИНСТИТУТОТ ЗА ФОЛКЛОР ВО ПРВИТЕ ДВЕ ДЕЦЕНИИ НА 21 ВЕК
}

Апстракт: Истражувањето се осврнува на теренските и на архивските истражувања и особено на истражувањето на Архивот на Институтот за фолклор „Марко Цепенков“" и на предизвиците што ги нудат тие во научните истражувања, како културна меморија на фолклорното, на етнолошкото наследство, односно на нематеријалното културно наследство, на негова промоција, заштита и на негово претставување. Заштитата на архивските материјали се надоградува со дигитализација на Архивот на Институтот за фолклор.

Клучни зборови: теренски истражувања, Архив на Институтот за фолклор, нематеријално културно наследство, културна меморија, промоција, заштита.

Крајот на XX и почетокот на XXI век, односно почетокот на новиот милениум, се одликуваше со глобални промени во општествено-економски, политички и идеолошки поглед, кои неминовно доведуваат и до промени во хуманистичките науки, а следствено на тоа и во фолклористиката и во етнологијата, со што доаѓа и до промена на перцепцијата на дисциплинарниот идентитет, особено во контекст на интердисциплинарноста. Во согласност со тоа и институтските истражувања, во првите две децении на XXI век, беа подложни на многу предизвици. Истражувањето се осврнува на теренските и на архивските истражувања и особено на истражувањето на Архивот на Институтот за фолклор „Марко Цепенков“ и на предизвиците што ги нудат тие, како културна меморија на фолклорното, етнолошкото наследство, односно на нематеријалното културно наследство, на негова промоција, заштита и на негово претставување.

Фолклористиката, етнологијата и социокултурната антропологија се втемелуваат како емпириски науки, кои, до сознанието, настојуваат да дојдат со теренски истражувања. Во согласност со тоа и основните истражувања на Институтот за фолклор „Марко Цепенков“, почнувајќи од неговото основање, се темелат на теренските истражувања, со што континуирано се бележи и се следи состојбата во сите сегменти на: духовната, материјалната и социјалната култура. Ова убаво се гледа уште со формирањето на Институтот, во Уредбата на Владата на Народна Република Македонија, број 1183, од 6.4.1950 година (тогаш како Фолклорен институт, самостојна научна институција од посебен национален интерес, со седиште во Скопје), каде што стои дека примарна задача на Институтот е да се собира, да се систематизира и да се конзервира фолклорното богатство на македонскиот народ.

Во Членот 2 од Уредбата на Владата на НРМ пишува: „задачите на Институтот се следни: 
1. да ја организира работата на собирањето, систематизирањето и конзервирањето на фолклорното богатство на македонскиот народ;

2. да го научно анализира, прочистува и обработува собраниот материјал од подрачјето на националниот фолклор;

3. да дава совети и стручни мненија во врска со применувањето на нашата народна уметност во домашните ракотворби, музиката, индустријата, градежништвото итн.;

4. да соработува со организации, друштва и установи коишто работат на пропагирањето на нашата народна уметност од територијата на Федеративна Народна Република Југославија и во странство, и да се грижи за чистоќата и изворноста на нашата народна уметност;

5. да се грижи за запазување и понатамошно развивање на нашето народно уметничко творчество;

6. да издава научни и научно-популарни публикации од областа на својата работа“"

(цит. спор. Малинов 2020: 5).

Следејќи ги основните постулати од основањето на Институтот, но, и фактот дека фолклористиката, етнологијата, социокултурната антропологија се емпириски науки, теренските истражувања се клучни во бележењето и во следењето на состојбата во сите сегменти на: духовната, материјалната и социјалната култура. Токму поради оваа причина, прашањето за теренот треба да биде постојано во центарот на вниманието, што подразбира континуирано размислување за него, како и негово преиспитување. Истражувачите, кои работеле во Институтот за фолклор „Марко Цепенков“, оставиле огромен фонд снимен архивски материјал, односно околу 4000 магнетофонски ленти co: песни, приказни, легенди, кратки фолклорни форми, етнографски материјали, ора итн., фотодокументација од над 3000 фотографии и неколку видеозаписи. Исто така и сегашните истражувачи во Институтот за фолклор собираат голем и значаен број архивски материјал, но, она што треба да се истакне е дека во последната деценија, теренските истражувања се значително намалени, што се должи на незначителното финансирање. Но, тоа не значи дека се прекинува со оваа дејност. Може да се каже дека размислувањата за теренските истражувања се актуализираат на крајот на XX век, што е и во врска со новите трендови во: фолклористичките, етнолошките, антрополошките истражувања, кои во центарот на истражувањето го поставиле современото општество, и некои негови сегменти, на пр.: идеологијата и политиката, економијата, урбаниот живот, глобализацијата, а ако овие истражувања се занимаваат со традиционалните модели, тоа го прават на начин, кој, во светската наука, е елабориран во XX век и темелно е преиспитан во последните две децении (Петреска 2019: 5). Теренските истражувања беа предмет на истражување и во соседните земји (кај авторите: Прица 1988: 105-111; Ковачевић 2005: 11-19; Иванова 2005: 19-27; Радојичић 2005: 115-121; Ивановић 2005: 123-141; Жикић 2012: 27-44; Turk Niskač 2011: 125-148; како и во зборниците: Etnologija bliskoga 2006; Теренска 


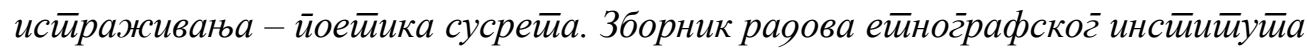
бр. 27, 2012), а помалку истражувања има кај нас (да се види, на пр.: Макеоонски фолклор бр. 17, 1976; Макеоонски фолклор бр. 37, 1986; Крстева 2005: 141-144; ЕтноАнтропоЗум бр. 7, 2009; Ашталковска 2016; зборник

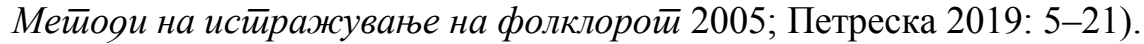

Тргнувајќи од фактот дека „народната“, „традиционална“ култура е динамична, тоа значеше и постојано преиспитување на теренот, особено методите на теренските истражувања. Ако, поранешните теренски истражувања, се карактеризираа, обично, со еднонеделно одење на терен главно во селски средини и основниот пристап при теренските истражувања се состоеше во снимање на материјалот на: магнетофонска лента, касета, диктафон, понатаму внимание почна да се обрнува и на непосредните забележувања, како и непосредните забележувања со учествувања (да се види повеќе: Петреска 2019: 6-9). Во слична насока размислуваат и други истражувачи во соседните земји. Така Р. Иванова забележува:

... јасно е дека промената на точката на гледиште на традиционалната култура ја става на дневен ред, пред сѐ, неопходноста на ширење и на збогатување на методот на теренска работа. На терен, истражувачката работа е тешка и сложена. Истражувачот треба да набљудува и да ја изучува објективната реалност онаква каква што е денес, да ја набљудува целата култура за да ги открие традиционалните лостови, кои ги започнуваат и покренуваат тековните општествени процеси и појави...

(Иванова 2005: 23).

Барањето за започнувањето на истражувачкиот процес во современоста подразбира воспоставување на набљудувањето како основен теренски метод, кое доскоро во потполност беше заменувано со интервју и со усмени анкети меѓу најстарите носители на традицијата, додека денес, набљудувањето е неопходно како за изучување на современата култура, така и за откривање на традиционалните механизми, кои се скриени под површинските слоеви на модерноста. Се разбира дека набљудувањето не ги исклучува досегашните користени методи. Меѓу нив посебно се истакнуваат: автобиографскиот метод, истражувачкиот дневник, како и пишаните извори со етнографски информации (архиви, периодични изданија, популарна литература и др.; Иванова 2005: 23-24).

Зорица Ивановиќ истакнува:

Истражувањата, кои се потпираат на набљудување со учествување без оглед на кој регион, за која тема или за кој истражувачки проблем се работи, можат да отворат значајни теориски проблеми и да дадат релевантни одговори и затоа теоријата е можно да се развива само преку етнографија. Со други зборови, теориите се развиваат, се разработуваат и се редефинираат низ етнографијата и низ етнографските детали

(Ивановић 2005: 139). 
Врз основа на претходнокажаното, современите фолклористички и етнолошки истражувања се заложуваат за истражување со содејствување и истакнуваат дека не е доволно само едноставно да се соберат податоци (од поединечни информатори) за општи теми, туку е потребно и набљудување на индивидуалните и на колективните дејствувања, собирање на кажувања, кои не се размислувани претходно или известувања за општеството - општо, за поединечниот живот, кој се живее во моментот. Во ваков случај можеме да се сложиме со Џејмс Клифорд (Clifford), според кого културата е отворен и креативен дијалог меѓу поткултурите, меѓу оние што се нејзини припадници и оние што се надвор од неа, меѓу различните страни (Augé 2002: 39).

Набљудувањето, како истражувачки процес, може да ги открие традиционалните механизми зад модерните и постмодерните културни случувања (традиционалните или дури архаични стереотипи во модерната политичка култура, печатените и електронските медиуми, како нова форма на традиционални механизми за предавање и за зачувување на информацијата; новите песни, кои можат да се гледаат како форма на традиционално пренесување; како и форми на „традиционалност“, кои се јавуваат во новото време), но кај кои се гледа потрошувачката, консумерска култура (БеновскаСъбкова 2004, 31; Иванова 1997; Петреска 2008; Мейояи на йроучување на

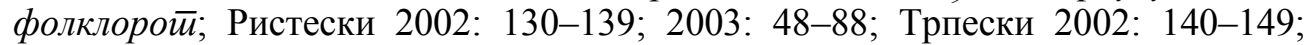
2003: 90-100; Bauzinger 2002: 309, 316-318). Ваквите пристапи доведуваат и до нови размислувања и организирања на теренот (видете повеќе: Петреска 2019: 5-21; Петреска 2020а: 52). Иако, глобализацијата и влијанието на западната култура зема голем замав, и како главна нивна одлика е консумерската потрошувачка култура и економската добивка, сепак традиционалните елементи вешто се вклопуваат во модерноста. Во оваа смисла, особено би го споменала влијанието на електронските медиуми, различните социјални мрежи, како и различните форуми, кои, во современоста, можат да се гледаат како еден вид пренесување на информации за традицијата. Дека пишаните и електронските медиуми и интернетот можат да се користат како теренски истражувања, се согласуваат и други истражувачи (Гавриловић 2005: 144-150; Etnografije interneta 2004). Како илустративен пример се значајните настани во семејниот живот, за кои многу често се вели дека се подложни на влијанието на западната култура, но, на интернетските страници многу често се сретнуваат традиционални елементи. Tоа се сретнува при канење кум во современите свадби, каде што иако, на пример, некаде кумот се кани со виски, некаде со ракија, значаен момент е украсувањето на шишето, што може да се гледа и како замена за украсената „карта со вино“, со која се канел кумот, но и значителното место што го имал кумот во традиционалната култура и специјалниот начин на канење. Тука е и канењето на старосватот/старосватицата, но, она што сѐ почесто се јавува во 
новото време е кумот да биде од машката, а старосватицата ${ }^{1}$ од женската страна, што оди во прилог на тоа дека и традиционалните механизми, поради новите услови, се подложни на промени. Ова, исто така, се однесува и на кумот, каде што традиционалниот кум, кој се наследувал со генерации, е заменет со избор на кум на другарска, пријателска основа кога може да се зборува за лабаво ритуално сродство или пак за симболичко сродство (Петреска 2005: 120, 161; Петреска 2020: 30-31; 115). Исто така, можеме да го споменеме раѓањето на дете, каде што многу значајни настани што биле карактеристични за традицијата, можат да се видат и во современоста. Да се споменат мекиците што ги дава семејството, кое добило новороденче. Проодувањето на детето било особено значаен момент што, семејството, го одбележувало со месење обредни лепчиња наречени „постапалки“, кои им се раздавале на роднините и на соседите. Во денешно време, на интернетски страници, се нудат понуди за правење „постапалки“, рецепти за нивно правење, но има и калапи што се продаваат во форма на детски ножиња. ${ }^{2}$

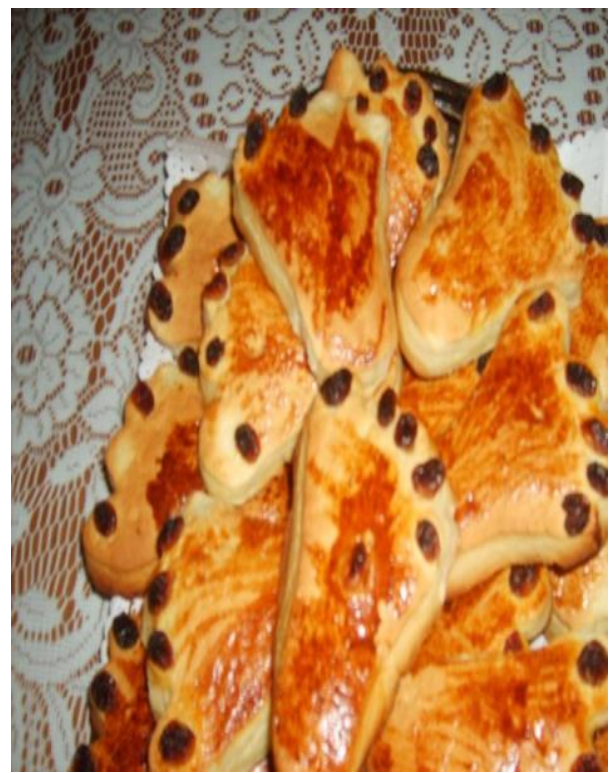

Постапалки ${ }^{3}$

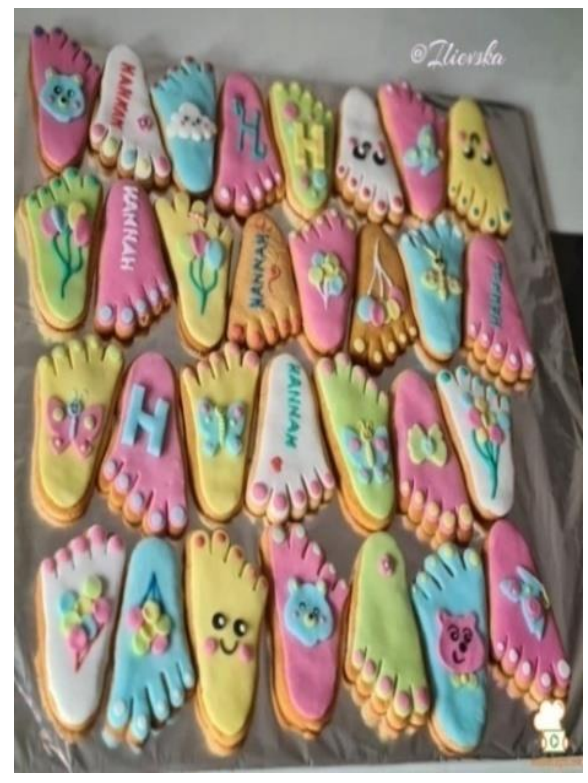

Постапалки ${ }^{4}$

\footnotetext{
1 За старосват/старосватица да се види повеќе: Весна Петреска. 2005. Систем на сродство кај Македонщите. Посебни изданија, кн. 59. Скопје: Институт за фолклор „Марко Цепенков“, 80-81.

${ }^{2}$ https://forum.femina.mk/threads/\%D0\%9F\%D0\%BE\%D1\%81\%D1\%82\%D0\%B0\%jue... ; https://www.ex.mk/index.php/pribor-za-domakinstvo/kalapi-za-pecenje/kalapi-zapostap...

${ }^{3} \mathrm{https}: / /$ moirecepti.mk/post/postapalki

4 https://moirecepti.mk/post/декорација-на-постапалки
} 


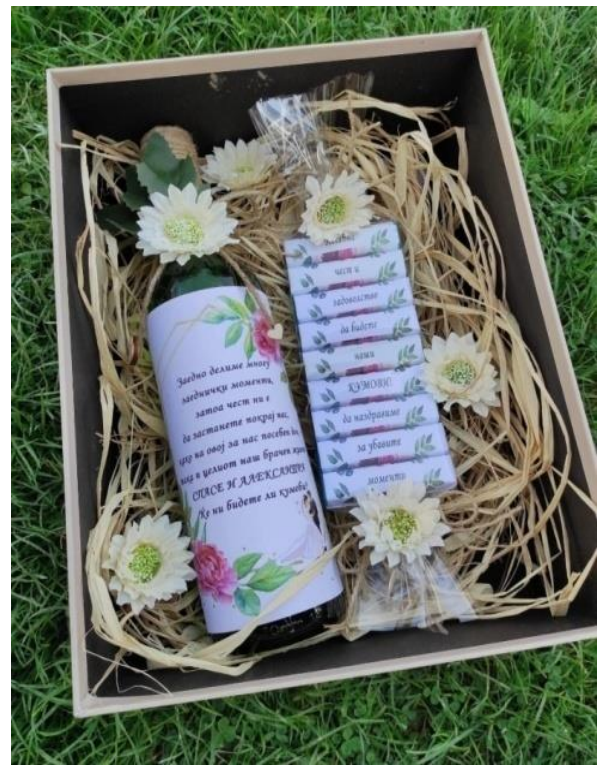

Покана за кумови ${ }^{5}$

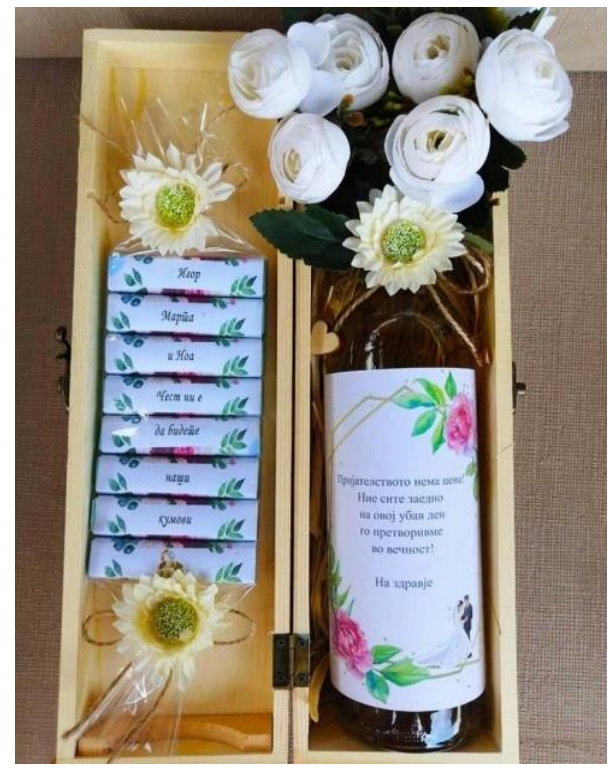

Покана за кумови 6

Меѓутоа, за да можат да се откријат традиционалните нитки во современата култура, треба добро да се познава традиционалната/народната култура, која неминовно е подложна на промени. Оттука, се допира и

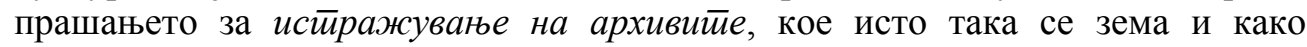
теренско истражување (за архивите како теренско истражување да се види: Радојичић 2005: 115-121; Радојичић 2012: 77-86; Радојичић 2020). Истражувачите, кои се занимавале со истражување на архивите, истакнале дека се тие интердисциплинарни установи поради нивната разновидна дејност и истовремено на современ начин се свртени и кон културата, кон управата, кон науката, кон образованието (Радојичић 2020: 10). Но, и при истражување на архивите треба да се земе предвид контекстот кога е истражувано. Во оваа смисла би го споменала огромниот фонд со кој располага Архивот на Институтот за фолклор, кој континуирано се збогатува почнувајќк од неговото основање. Меѓутоа, значително негово збогатување настанува за време на раководењето на Институтот за фолклор од страна на Блаже Ристовски (1966 - 1975), кој формира разгранета мрежа на собирачи на фолклорни и на етнографски материјали ширум Македонија (да се види: Малинов и Петреска 2017: 35; Малинов 2020: 12), меѓу кои особено треба да се истакне г. Иван Котев, кој, во Институтот за фолклор, остави значителен фонд на фолклорен материјал. Значајноста на Архивот на Институтот за

${ }^{5}$ https://www.vinozito.mk/products/podarok-za-pokana-za-kumovi

6 https://www.vinozito.mk/products/podarok-za-kumovi 
фолклор може да се согледа и надвор од земјата бидејќи тој е влезен и во светски организации како ИСФН (International Society for Folk Narrative Research: ISFNR, http://isfnr.org/files/european-folklore-archives.html).

Истражувањето на Архивите, во овој случај на Архивот на Институтот за фолклор, во кој можат да се најдат драгоцени информации, дава можност за поврзување на архивите и науката, што континуирано го прават истражувачите во Институтот за фолклор. Би истакнала дека во денешно време можеби повеќе треба да се посвети внимание на архивските материјали со кои располага Архивот на Институтот, кои, како најстари од овој вид во државава (1950 г.), даваат драгоцени податоци како за хоризонтален, така и за вертикален континуитет на настаните. Затоа, архивските материјали, покрај улогата на зачувување и пренесување на фактите од минатото, претставуваат значајна подлога за научна работа и може да се каже дека често тие се и еден од најважните извори. Затоа, и Бернард Стули истакнува дека главниот корисник на архивите во современата општествена практика е науката, а со тоа вредноста и општествената улога на архивите, во поголем дел, ја запознава пошироката јавност посредно преку објавување на резултатите од научните истражувања (според: Радојичић 2020: 11; сп. Stulli 1977: 15), слично како што и Р. Бендик, кој истакнува дека архивите се функционални установи, кои во некои случаи се водени од силното интересирање за меѓусебно поврзување на архивите и на дисциплинарната практика (Радојичић 2020: 11; сп. Bendix 2015, 143-163).

Веќе е истакнато дека архивите даваат значаен фонд на знаење за начинот на живот на определен простор, за културните традиции и за културните практики на населението, што даваат можност за нивно етнолошко, фолклористичко, антрополошко читање, а вакво „читање“ особено дава Архивот на Институтот за фолклор, за кој слободно може да се каже дека во него е зачувана културната меморија на фолклорното и на етнолошкото наследство. Ова го велам од причина што за проучување на определена појава со сите трансформации што се неизбежни, многу е значаен квантитетот и континуитетот. Затоа, уште постарите истражувачи истакнале дека за поуспешни истражувања, значајно е, во архивите, да постои колку што е можно подолг временски континуитет на записи. Ѓ. Петровиќ уште во 1979 година истакнала дека за разлика од усмените извори, кои подробно го фиксираат, обично, определеното време и прават хоризонтален пресек, архивската граѓa претставува најпрецизен информатор за објективно утврдување на историските димензии, што го прави и вертикалниот пресек и помага точно да се согледаат процесите и содржините кај појавите од доменот на културата на минатите и на неодамнешни денови (Радојичић 2020: 12; сп. Petrović 1979: 157-159). Ова значи дека за покомплетно истражување или за длабинско истражување на определена проучувана култура, таа треба да се истражува како на вертикално, така и на хоризонтално ниво, а тоа е овозможено преку истражување на архивите. Но, исто така, во зависност од темата, е пожелно да се користат сите видови расположливи извори, кои можат да дадат драгоцени податоци. Особено ова се однесува на современите етнолошки, антрополошки истражувања, кои се протегаат од минатото кон 
иднината, од историските извори сочувани во архивите, сѐ до виртуелните, дигитални светови (Радојичић 2020: 13). Накратко, истражувањето во Архивите, во овој случај го земам Архивот на Институтот за фолклор, дава можност за следење на културните феномени во историска ретроспектива, што помага да се дојде до сознание за подобро запознавање на нас самите, што е особено важно во: етнолошките, фолклористичките и антрополошките истражувања. Следењето на културните феномени овозможува да се разберат различните традиции и наследства, кои се пренесуваат и во современите процеси и како такви се чуваат и се одржуваат постанувајќи определено добро на различни култури или пак се едноставно практики со кои се соживуваат човечките заедници. Затоа, во денешно време истражувањето во Архивите може и да не се смета како атрактивна работа. Повеќе се настојува да се дојде до сознанија само врз основа на теренски истражувања собрани во најнов период или пак да се дојде до сознанија по алтернативни патишта што го нуди технолошкиот развој (медиуми, интернет). Но, сепак, истражувањето на архивите е значајно затоа што тие даваат можност да се следат: појавите, процесите и трансформациите во нивниот историски континуитет. Секако дека треба да се земе целокупниот контекст на времето и на просторот кога се собирани.

Технолошкиот развој, односно употребата на современите информациски системи, е исто така значаен за дигитализација на архивите. Создавањето база на архивски документи во дигитална форма е значајно за истражувањето поради полесната достапност и подобра зачуваност на архивската граѓa, со други зборови, ги спасува од заборав, земајќки ги предвид несоодветните услови за чување на архивските материјали во просториите на Институтот за фолклор. Во оваа смисла треба да се спомене дигитализацијата на дешифрираниот материјал во Архивот на Институтот за фолклор, која почна да се спроведува преку проектот за идентификација и дигитализација на архивскиот фонд на Институтот за фолклор „Марко Цепенков“, финансиран од Министерството за култура на РМ. Преку овој проект, голем дел од дешифрираниот архивски материјал од снимени ленти е дигитализиран, но, останува лентите да се пренесат на современи носачи на звук бидејќ времето си го прави своето, па може да се случи и голем дел од лентите да не можат да се преслушаат. Треба да се спомене и дигитализацијата на неколку видеозаписи на ора од Михајло Димовски што ја направи м-р Стојанче Костов. Би споменала дека и во дигитална форма се пренесени најстарите етнолошки материјали депонирани во Архивот на Институтот за фолклор, собрани во периодот од 1950 г. до 1962 г., од првите етнолози вработени во Институтот: Марика Хаџи-Пецова, Вера Славејкова, Миодраг Хаџи-Ристиќ, нивниот професор Бранислав Русиќ и Јосиф Јосифовски. Во тој период теренските истражувања се изведувале со пишување на рака, што значи дека не постоеле магнетофони за снимање, а потоа материјалите биле препишувани на машина за пишување. Во Институтот се чуваат во папки во кутии и има околу 80 папки, со некаде околу 1600 страници. Овој проект беше во реализација на д-р Зоранчо Малинов и д-р Весна Петреска, научни советници во Институтот за фолклор „Марко Цепенков“ (Малинов и Петреска 2020). 
Користењето на архивите, односно архивската граѓ, дава можност и за промоција на културното наследство. Така, се очекува голем дел од дигитализираниот архивски материјал, со кој располага Институтот, да биде достапен до научната и до пошироката јавност во вид на каталог, или пак да бидат достапни содржинските листови со архивскиот материјал, дел од дешифрираниот и од мелографираниот материјал, како и материјали од фототеката, аудиотеката (звучните записи) и кинотеката (видеоматеријалите) (Малинов 2020: 13).

Промоцијата на културното наследство се гледа и преку неговото прилагодување за современи услови. Во оваа смисла би го споменала маестро Симон Трпчевски кој, користејќи го Архивот, преработи и неколку песни и ора на познатиот албум „Светско, а наше - Македонисимо“, кое беше претставено во многу земји (Германија, Велика Британија, Полска, Србија, Холандија), што истовремено е и промоција на македонскиот фолклор (YouTube - Промоција на Македонисимо на Симон Трпчевски, Сител Телевизија, 7.9.2020). Промоцијата на културното наследство и неговото прилагодување за сценски настап се гледа и преку културните манифестации (Петровска-Кузманова 2009; 2017: 180-195).

Забрзаните промени во новото време, кои неминовно доведуваат до губење на елементи на традицијата, на народната култура, кои сега се гледаат како нематеријално културно наследство, го отвораат и прашањето за негова заштита, која е една од перспективите на фолклористичките и на етнолошките истражувања. Институтот за фолклор „Марко Цепенков“ е овластен субјект за заштита на нематеријалното културно наследство и неговите истражувачи имаат изработено над 60-ина елаборати за валоризација на нематеријалното културно наследство, кои се изработени за потребите на Управата за заштита на културното наследство при Министерството за култура. Неколку елаборати изработени од вработените во Институтот за фолклор се впишани на Репрезентативната листа на нематеријалното културно наследство на човештвото на УНЕСКО, еден е на Листата за потребата од итна заштита на нематеријалното културно наследство на човештвото на УНЕСКО, а неколку се и на Националната листа на заштитени нематеријални културни наследства (Малинов 2020: 10; Петреска 2020а: 52-53). Треба да се истакне дека и при изготвувањето на елаборатите за заштита неминовно е истражување во Архивот на Институтот за фолклор, како и теренски истражувања за согледување на современата состојба и дали е жива традицијата. Всушност и културните политики на земјите се насочени кон: претставување, промовирање и употреба на културните традиции, каде што, покрај идентитетот, е неизоставно добивање и на капитал, а со самото тоа е видлива перформативната страна на фолклорот бидејќи политиките се насочени кон заштита на живото културно наследство (Петреска 2020: 53).

Како заклучок на сето претходно кажано во врска со теренските истражувања како основа на фолклористичките, на етнолошките и на антрополошките истражувања и истражувањето на Архивот на Институтот за фолклор, може да се каже дека тие ни го отсликуваат животот во минатото, потоа културните традиции, па затоа тие може да се сметаат и како културна 
меморија. Разновидните традиции и наследства, иако се подложни на промени, се текови на современите процеси што се чуваат, се одржуваат и се прилагодуваат на новонастанатите услови, постанувајќи културно добро на различни култури или пак се едноставно практики со кои луѓето се соживеале. Истражувањето на Архивите, како и теренските истражувања се значајни и за заштита на нематеријалното културно наследство, но и за негова промоција.

\section{ЛИТЕРАТУРА}

\section{Кирилични изданија}

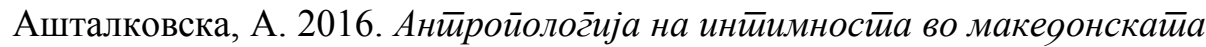
нарояна кулйура. Скопје: Природно-математички факултет, Институт за етнологија и антропологија.

Беновска-Събкова, М. 2004. „Размисли върху методите за проучване на традиционната култура в съвременността“. Ейно-кулйуролошки зборник, кн. 9. Сврљиг, 29-34.

Гавриловић, Љ. 2005. „Прелудијум за антропологију медија“.

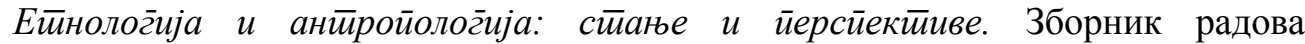
етнографског института бр. 21. Београд: Етнографски институт САНУ, 143 150 .

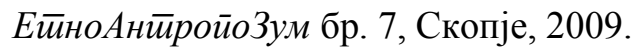

Жикић, Б. 2012. „Произвођење научног знања истраживачким методама теренског рада у етнологији и антропологији“. Теренска исирраживања $\bar{u} о е \bar{u} и к а ~ с у с р е \bar{u} а$. Зборник радова етнографског института бр. 27. Главни и одговорни уредник Радојичић, Д.; ур. М. Ивановић-Баришић. Београд: Етнографски институт САНУ, 27-44.

Иванова, Р. 1997. Сбог̄ом яинозаври, фобре яошли крокояили: ейнолог̄ия на йроменийе. София.

Иванова, Р. 2005. „Бугарска етнологија - стање и перспективе“.

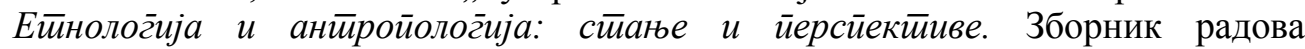
етнографског института бр. 21. Београд: Етнографски институт САНУ, 21-27.

Ивановић, 3. 2005. „Терен антропологије и теренски истраживање пре и

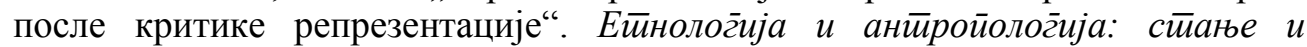
иерсиекийве. Зборник радова етнографског института бр. 21. Београд: Етнографски институт САНУ, 123-141.

Ковачевић, И. 2005. „Из етнологије у антропологију. (Срйска

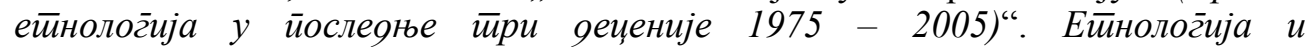

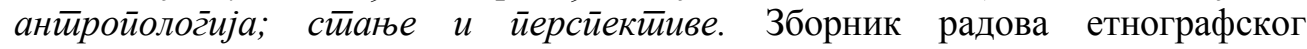
института бр. 21. Београд: Етнографски институ САНУ, 11-19.

Крстева, А. 2005. Размислувања за потребата од теренски етнолошки истражувања. Ейнолог̄, VIII/11, Скопје, 141-144;

Макеоонски фолклор, бр. 17, 1976. Скопје: Институт за фолклор „Марко Цепенков“.

Макеоонски фолклор, бр. 37, 1986. Скопје: Институт за фолклор „Марко Цепенков“". 
Малинов, 3. 2020. „Кон јубилејот (Краток преглед на 70-годишната историја на Институтот)“. 70 гооини Инстиийуй за фолклор „Марко Цейенков" (1950 - 2020). Редакција д-р 3. Малинов и д-р К. ПетровскаКузманова. Скопје: Институт за фолклор „Марко Цепенков“.

Малинов, 3. и В. Петреска. 2017. „Придонесот на Институтот за фолклор 'Марко Цепенков' во развојот на македонската етнологија“. Ейнолог, бр. 18, 20-39.

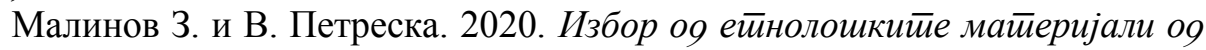

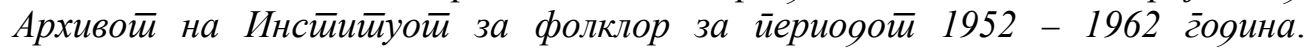
Институт за фолклор „Марко Цепенков“, Скопје, CD - издание.

Стојановиќ-Лафазановска, Л. (ур.) 2005. Мет̄ояи на истиражување на фолклороти. Посебни изданија, кн. 60. Скопје: Институт за фолклор „Марко Цепенков“.

Петреска, В. 2005. Систием на сроясйво кај Макеgонцииее. Посебни изданија, кн. 59. Скопје: Институт за фолклор „Марко Цепенков““.

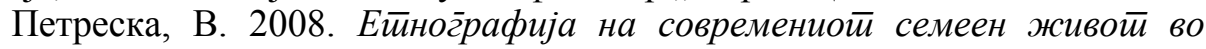

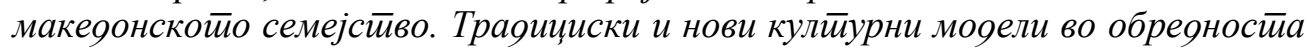
и семејнио $\bar{u} ж и в о \bar{u}$. Посебни изданија, кн. 70. Скопје: Институт за фолклор „Марко Цепенков“.

Петреска, В. 2019. „Од терен до научен текст: методолошки и етички прашања при теренските истражувања“. Македонски фолклор, бр. 75. Скопје: Институт за фолклор „Марко Цепенков“, 5-21.

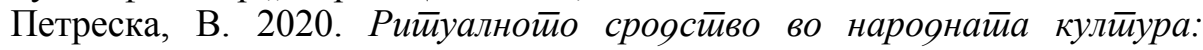
сеќавање и йрейстиавување на минайойо йреку религичско-обреяна йракса. Посебни изданија, кн. 87. Скопје: Институт за фолклор „Марко Цепенков“.

Петреска, В. 2020а: „Предизвици на современите фолклористички и етнолошки истражувања“. Макеgонски фолклор, год. LI, бр. 77-78. Скопје: Институт за фолклор „Марко Цепенков“, 49-60.

Петровска-Кузманова, К. 2009. Асиеккйи на извеgбайа. Скопје: Институт за фолклор „Марко Цепенков”.

Петровска-Кузманова, К. 2017. „Традиција во современ контекст,

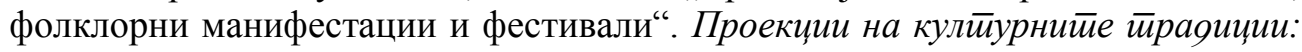
България - Макеgония. Издателство на БАН „Проф. Марин Дринов“. Софија, 180-195.

Прица, И. 1988. „Захтеви савремености у антрополошком поимању културе“. Ейнолошке свеске, IX, 105-111.

Радојичић, Д. 2005. „Архивски извори у реконструкцији живота“.

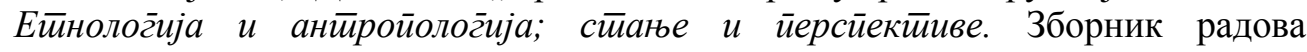
етнографског института бр. 21. Београд: Етнографски институт САНУ, 115121.

Радојичић, Д. 2012. „Примена архивске грађе у етнологији“. Теренска

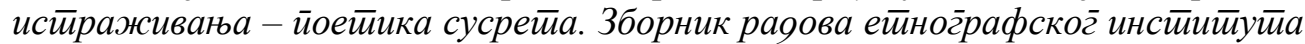
бр. 27. Главни и одговорни уредник Радојичић, Д.; ур. М. Ивановић-Баришић. Београд: Етнографски институт САНУ, 77-86. 
Радојичић, Д. 2020. Архив и анӣроӣолог̄ија сећања. Метроон: извори за етнологију и антропологију, књига 1, монографска издања. Београд: Етнографски институт САНУ.

Ристески, С. Љ. 2002. „Етничките симболи и политиката“.

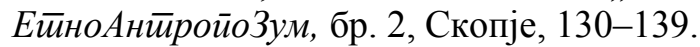

Ристески, С. Љ. 2003. „Дали македонскиот јазол станува песји јазол локален термин за јазол што многу тешко се одврзува“. ЕйноАнйройоЗум, бр. 3, Скопје, 48-88.

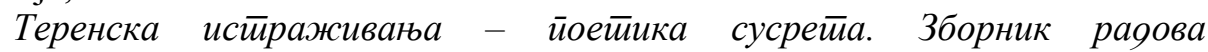

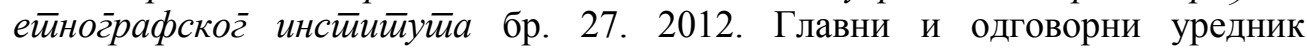
Радојичић, Д. ур. М. Ивановић-Баришић. Београд: Етнографски институт CAHУ.

Трпески, Д. 2002. „Сфаќањето на традицијата и на етничките карактеристики и нивната употреба во предизборната кампања““. ЕйноАнӣиройозум, бр. 2, Скопје, 140-149.

Трпески, Д. 2003. „Етномитовите на македонската политичка сцена“. ЕйноАнйройоЗум, бр. 3, Скопје, 90-102.

\section{Латинични изданија}

Augé, M. 2002. "Bliski drugi”. Drugi i sličan. Pogledi na etnologiju suvremenih društva. Zagreb, 25-42.

Bauzinger, H. 2002. Etnologija. Od proučavanje starine do kulturologije. Beograd: Biblioteka XX vek.

Etnologija bliskoga: Poetika i politika suvremenih terenskih istraživanja. 2006. Ur. J. Capo Žmegac, V. Gulin Zrnić i G. Pavel Šantek. Zagreb: Institut za etnologiju i folkloristiku, Biblioteka Nova Etnografija.

Etnografije interneta. 2004. Ur. Senjaković, R. i I. Pleše. Zagreb: Institut za etnologiju i folkloristiku, IBIS Grafika.

Turk Niskač, B. 2011. "Some thoughts on ethnographic fieldwork and photography". Studia etnologica croatica, vol. 23, 125-148;

\section{Сајтографија}

„Постапалки“"

https://forum.femina.mk/threads/\%D0\%9F\%D0\%BE $\% \mathrm{D} 1 \% 81 \% \mathrm{D} 1 \% 82 \% \mathrm{D} 0 \% \mathrm{~B} 0$

$\% \mathrm{D} 0 \% \mathrm{BF} \% \mathrm{D} 0 \% \mathrm{~B} 0 \% \mathrm{D} 0 \% \mathrm{BB} \% \mathrm{D} 0 \% \mathrm{BA} \% \mathrm{D} 0 \% \mathrm{~B} 8.22560 /$ [Пристапено на 5.10.2021].

„Калапи за печење постапалки“ https://www.ex.mk/index.php/pribor-zadomakinstvo/kalapi-za-pecenje/kalapi-za-postapalki-detail) [Пристапено на 5.10.2021].

„Постапалки“ https://moirecepti.mk/post/postapalki [Пристапено на 5.10.2021].

„Декорација на постапалки“ https://moirecepti.mk/post/декорација-напостапалки [Пристапено на 5.10.2021]. 
„Покана за кумови“ https://www.vinozito.mk/products/podarok-za-pokanaza-kumovi [Пристапено на 5.10.2021].

„Belief Narrative Network“ http://isfnr.org/files/european-folklorearchives.html [Пристапено на 5.10.2021].

Промоција на Македонисимо на Симон Трпчевски, Сител Телевизија, 7.9.2020 https://www.youtube.com/watch?v=HxYkEOUG18I [Пристапено на 10.10.2021].

Vesna Petreska

\title{
ARCHIVAL AND FIELD RESEARCH AS CHALLENGES FOR THE FOLKLORISTIC RESEARCH AT THE INSTITUTE OF FOLKLORE IN THE FIRST TWO DECADES OF THE $21^{\mathrm{ST}}$ CENTURY
}

\author{
Summary
}

Folklore, ethnology and sociocultural anthropology are established as empirical sciences, which seek knowledge in field research. Respectively, starting from its foundation, the principal research of the "Marko Cepenkov" Institute of Folklore was based on field research, through which all segments of the spiritual, material and social culture are being observed.

The research relates to the field and archival research, in particular the research of the Archive of the "Marko Cepenkov" Institute of Folklore, which are an important base for a scientific work and countless challenges. It is important to enrich field with archival research, especially with the research of the Archive of the "Marko Cepenkov" Institute of Folklore, which was founded in 1950 as one of the oldest institutions in the country. In this way we can keep track of the occurrences, processes and transformations of the cultural phenomena in their historical continuity. However, since the archives reflect the life in the past, as well as numerous cultural traditions, they can be considered as a type of cultural memory of the folkloric and ethnological heritage. We should also mention that the use of current information systems is essential in terms of digitalization of the archives. The creation of digitalized archival documentation is of great importance due to easier availability and better preservation of the archive material. The research of the Archives, as well as the field research, is essential for the protection of the intangible cultural heritage, as well as its presentation and promotion. 